\title{
Dziedzice Konarów herbów Ostoja i Szreniawa Analiza historycznoprawna
}

Badania nad Konarskimi (herbu Gryf) doprowadziły piszącego te słowa do konstatacji, że w ich późniejszych dobrach Konary (parafia Nawarzyce), w powiecie ziemskim krakowskim (dawniej pow. Książ Wielki), wcześniej występowały inne rody, piszące się „z Koszyc i Konarów” oraz „z Grodziny i Konarów”.

\section{Część I. Ród herbu Ostoja}

\section{Wincenty}

Dnia 22 maja 1361 r. Kazimierz III Wielki zatwierdził wyrok sędziego krakowskiego Jana (z Grębynic), przysądzający Wilhelmowi opatowi i klasztorowi jędrzejowskiemu pole w Konarach koło Opatkowic w stronę Łysakowa na prawo, wbrew pretensjom Wincentego, dziedzica z Koszyc (pow. pilzneński,

${ }^{1}$ Grodzina: 1229 Grodina, 1326 Grodzina, 1355 Groczyna, Grohyna, 1376 Grogina, 1402 de Grodzin, 1581 Grudzina), dziś Grudzyny, $11 \mathrm{~km}$ na płd.-wsch. od Jędrzejowa. Zob. http:// www.slownik.ihpan.edu.pl/search.php?id=6193 [dostęp: 13.10.2018]. Konary: 1153 [1154] Konare, 1210 Konare, 1361 Konary, 1368 Conari, 1386 de Conarz, de Konar, 12 km na płd od Jędrzejowa. Zob. http://www.slownik.ihpan.edu.pl/search.php?id=7828 [dostęp: 13.10.2018]. 
herbu Ostoja?) i Dobiesława z Ławszowa (herbu Strzemię) $)^{2}$ Wincenty z Koszyc został tu umieszczony, bo rodzi się pytanie, czy nie był to przodek podsędka krakowskiego Dobiesława z Koszyc i Konarów herbu Ostoja, choć jego imię raczej wiąże go z Dobiesławem z Ławszowa (ob. Łapszów), teściem Mikołaja z Grodziny i Konarów. Imię Dobiesław było jednak popularne (zob. niżej).

\section{Sągniew}

Dnia 1 sierpnia 1376 r. Pełka, sędzia, i Prandota, podsędek ziemi sandomierskiej w Opatowie, potwierdzili, że Wrocław i jego synowie Andrzej, Dobiesław i Nieczuja z Wysok sprzedali udział Sągniewowi, dziedzicowi z Konarów (Sangnewo heredi de Conari) $)^{3}$. W dniu 8 stycznia 1388 r. Pełka, sędzia, i Prandota, podsędek ziemi sandomierskiej w Sandomierzu, potwierdzili zbycie części wsi Krobielice za 60 grzywien przez Światosława (zwanego) Czarny Płaszcz i jego brata Przybysława oraz syna Marcina, dziedziców wsi Pstronnej opatowi i konwentowi koprzywnickiemu. Jednym ze świadków był domino Sagnewo de Konari $^{4}$. Tego ostatniego utożsamił Stanisław Kuraś z Sangnewo de Cernini, występującym jako świadek, gdy Pełka, sędzia, i Prandota, podsędek ziemi sandomierskiej, 7 września 1386 r. w Opatowie potwierdzili, że bracia Wyszko i Wojsław zbyli Jakubowi, prepozytowi i konwentowi klasztornemu w Trzemeśnie, część wsi Jeżowa za 100 grzywien5 ${ }^{5}$ Być może był to syn Wincentego i ojciec Dobiesława.

\section{Zbigniew}

W dniu 9 września 1380 r. Pełka, sędzia, i Prandota, podsędek ziemi sandomierskiej w Sandomierzu, potwierdzili imiennie wymienionych miejscowości Piotra i Jakuba, 21 synów zmarłego Eustachiusza. Jednym ze świadków był domino Zbigneo de Conari ${ }^{6}$. Być może był to brat Sągniewa.

${ }^{2}$ Kodeks dyplomatyczny Małopolski. [T. 1]: 1178-1386. Wyd. F. Piekosiński. Kraków 1876, cyt. dalej: KDMłp, T. 1, nr CCLX (s. 307-308).

3 Zbiór dokumentów matopolskich. Cz. 4: Dokumenty z lat 1211-1400. Wyd. S. Kuraś, I. Sułkowska-Kuraś. Wrocław-Warszawa-Kraków 1969, cyt. dalej: ZDM, cz. IV, nr 1027 (s. $180-181$ ).

${ }^{4}$ Zbiór dokumentów matopolskich. Cz. 1: Dokumenty z lat 1257-1420. Wyd. S. Kuraś. Wrocław-Warszawa-Kraków 1962, cyt. dalej: ZDM, cz. I, nr 187 (s. 239-240).

${ }^{5}$ ZDM, cz. I, nr 181 różnica numerów - por. niżej (s. 233).

${ }^{6}$ ZDM, cz. I, nr 161 (s. 206-207). 


\section{Dobieslaw}

Dobiesław był zapewne synem lub wnukiem Wincentego. Był stolnikiem krakowskim (notowany 28 października 1392 -25 lipca 1393)7. Potem pełnił urząd podsędka ziemskiego krakowskiego (30 września 1394-27 sierpnia 1409) ${ }^{8}$. Jako zmarły został wspomniany 17 grudnia 1409 r. . Pierwszy raz został odnotowany jako świadek (Dobeslao Herede de Ceszczicze) 24 grudnia 1378 r., gdy kasztelan sandomierski Jan z Tarnowa odstąpił trzecią część z dochodów z młyna koło Tarnowa młynarzowi Frankowi za 20 grzywien $^{10}$. Dnia 28 października 1392 r. świadkował jako stolnik (Dobeslao dapifero), gdy Spytek, wojewoda i starosta krakowski, poświadczył, iż Dersław, syn Pełki, sędziego ziemskiego sandomierskiego, sprzedał Przewrocze i Porębę Janowi z Tarnowa ${ }^{11}$. W charakterze podsędka pierwszy raz został odnotowany 30 września 1394 r., gdy wraz z sędzią Drogomirem rozsądzali spór między miastem Wiślicą a Sułkiem i jego bratankiem, dziedzicem z Królewic ${ }^{12}$. Ta sama para wyrokowała 15 grudnia 1394 r. w sprawie między Paszkiem z Barućwierdzy i Hankiem z Chełmu ${ }^{13}$. Jako Dobeslao de Cosczice subiudice Cracouiensi świadkował na dokumencie Władysława II Jagiełły z 25 maja 1395 r., w którym poświadczono, że Jan z Tarnowa, wojewoda sandomierski, nabył Przewrocze i Porębę od Dersława, syna Pełki, sędziego ziemskiego sandomierskiegoo ${ }^{14}$. Dnia 3 lutego 1396 r. Dobeslaus subiudex Cracoviensis terre generales wraz z sędzią Drogomirem rozstrzygali spór kapituły gnieźnieńskiej z Piotrem i Wyszkiem z Siedlca o wieś Cierno ${ }^{15}$. Tego dnia zaświadczyli ponadto, iż Jakusz z Kozłowa sprzedał wieś Wolicę za 300 grzywien opatowi Jakubowi i konwentowi klasztoru cystersów w Jędrzejo-

${ }^{7}$ K. Federowicz: Dostojnicy i urzędnicy świeccy województwa krakowskiego w latach 1374-1506. W: Archiwum Komisji Historycznej. T. 8. Kraków 1898, s. 86.

${ }^{8}$ Dokumenty saqdu ziemskiego krakowskiego 1302-1453. Oprac. Z. Perzanowski. Wrocław-Warszawa-Kraków-Gdańsk 1971, cyt. dalej: DSZK, s. XL. U K. Federowicza 25 maja 1395-27 sierpnia 1409. Zob. Idem: Dostojnicy i urzędnicy świeccy..., s. 65. Urzędnicy dawnej Rzeczypospolitej XII-XVIII wieku. Spisy. Red. A. Gąsiorowski. T. IV/1: Urzędnicy matopolscy XII-XV wieku. Spisy. Oprac. J. Kurtyka, T. Nowakowski, F. Sikora, A. Sochacka, P.K. Wojciechowski, B. Wyrozumska. Wrocław 1990, nr 315 (s. 101) i nr 421 (s. 118), cyt. dalej: UM.

${ }^{9}$ DSZK, s. XL. Herb Ostoja podaje J. Kurtyka, http://www.slownik.ihpan.edu.pl/search. php?id=7828 [dostęp: 2.08.2017].

${ }^{10}$ Kodeks dyplomatyczny Polski. T. 3. Wyd. L. Rzyszczewski, A. Muczkowski. Warszawa 1858, cyt. dalej: KDP, T. 3, nr CLX (s. 320).

${ }^{11}$ Archiwum ksiąząt Lubartowiczów Sanguszków w Stawucie. Wyd. Z.L. Radzimiński, B. Gorczak. T. 2: (1284-1506). Lwów 1888, cyt. dalej: AS, T. 2, nr LXX (s. 83).

${ }^{12}$ DSZK, nr 64 (s. 71).

${ }^{13}$ DSZK, nr 65 (s. 72).

${ }^{14}$ AS, T. 2, nr LXXII (s. 86).

${ }^{15}$ Kodeks dyplomatyczny Wielkopolski. Lata 1350-1399. Wyd. J.I. Kraszew ski (dr W. Łebiński). T. 3. Poznań 1879, cyt. dalej: KDW, T. 3, nr 1966 (s. 686). 
wie $^{16}$. W dniu 11 kwietnia 1396 r. Drogomir i Dobiesław zatwierdzili, że Lambert, zwany Szypem, dziedzic w Pstroszycach zbył za 80 grzywien część dóbr prepozytowi Michałowi i konwentowi w Miechowie ${ }^{17}$. Dnia 11 grudnia 1396 r. para sędziów zatwierdziła kolejne nabycie dóbr przez tą samą instytucję od Dzierżka z Brzostku i jego żony Piechny oraz jej siostry Nastki w Brzuchani za 400 grzywien ${ }^{18}$. Dzień później zatwierdzili podobny kontrakt (ta sama miejscowość, ci sami nabywcy, inni zbywcy) ${ }^{19}$. Dnia 10 grudnia 1397 r. nowy sędzia Michał i dalej Dobiesław zatwierdzili kolejne nabycie dóbr (tym razem w formie darowizny w Pstroszycach) dla tej samej instytucji ${ }^{20}$. Dnia 7 stycznia 1398 r. Michał i Dobiesław zaświadczyli, że Krystyna (córka Trojana), dziedziczka w Parkoszowicach, zbyła swą część dziedziczną tamże (za zgodą ojca) za 300 grzywien Borkowi z Trzcińca ${ }^{21}$. W dniu 4 lutego 1398 r. Dobiesław (z Konarów), podsędek krakowski sądził się z klasztorem cysterskim w Jędrzejowie o niwę (pro niwa) koło łąk przed Konarami ${ }^{22}$. Nieco później 10 lutego 1398 r. (albo: tego samego roku) jako Dobeslao de Cosczicze subiudice Cracouiensi świadkował na dokumencie Władysława II Jagiełły, w którym poświadczono, że Jan z Tarnowa, wojewoda sandomierski, nabył połowę wsi Szczepanowice od Benka z Żabokru$\mathrm{ku}^{23}$. W dniu 23 lutego $1398 \mathrm{r}$. Dobiesław, podsędek, świadkował na dokumencie Władysława II Jagiełły, w którym poświadczono, że Pietrasz z Zabawy zapisał majątek mieszczanom krakowskim ${ }^{24}$. Dnia 7 czerwca 1398 r. wyrokował (wraz z sędzią Michałem) w sprawie wsi Łosośkowice ${ }^{25}$. W dniu 25 czerwca 1398 r. ci sami zatwierdzili kolejne nabycie dóbr przez wspomniane instytucje miechowskie $^{26}$. Dnia 8 lipca 1398 r. ci sami zaświadczyli, że Jan, dziedzic z Chodowa, zobowiązał się przedstawić Jaśkowi Piczkowi poręczycieli za swój dług i ustanowić zastaw ${ }^{27}$. Dnia 16 lipca 1398 r. Borzek z Olbrachcic, procesując się z Dobkiem podsędkiem o przeoranie 400 skib w Konarach, uzyskał już wyrok w pierw-

${ }^{16}$ DSZK, nr 66 (s. 73).

17 DSZK, nr 67 (s. 74).

18 DSZK, nr 68 (s. 75).

${ }^{19}$ DSZK, nr 69 (s. 76).

${ }^{20}$ DSZK, nr 70 (s. 77).

${ }^{21}$ DSZK, nr 71 (s. 78).

${ }^{22}$ Starodawne prawa polskiego pomniki. T. 8: Antiquissimi libri iudiciales terrae cracouiensis. Pars II: Ab an. 1394-1400. Editionem curauit B. Ulanowski. Cracoviae MDCCCLXXXVI, cyt. dalej: SPPP, T. 8, cz. 2, uwaga CCXLII (nr 1, s. 451).

${ }^{23}$ AS, T. 2, nr LXXIV (s. 89).

${ }^{24}$ Kodeks dyplomatyczny miasta Krakowa 1253-1506. Cz. 1. Wyd. F. Piekosiński. Kraków 1879, cyt. dalej: KDMK, cz. I, nr LXXXIX (s. 120).

${ }^{25}$ Kodeks dyplomatyczny Katedry Krakowskiej św. Wacława. Wyd. F. Piekosiński. T. 2. Kraków 1883, cyt. dalej: KDKK, T. 2, nr CCCCXXVII (s. 223). Dalej 18 VI t.r., nr CCCCXXIX (s. 224).

\footnotetext{
${ }^{26}$ DSZK, $\mathrm{nr} 72$ (s. 79).

${ }^{27}$ DSZK, $n r 73$ (s. 81).
} 
szym terminie $\mathrm{z}$ powodu niestawiennictwa Dobka ${ }^{28}$. Tego samego dnia analogicznie dla Dobka zakończyła się jego sprawa z Szymkiem Sułkowicem z Góry o poręczenie długów żydowskich ${ }^{29}$. W dniu 14 sierpnia 1398 r. Michał i Dobiesław poświadczali podział dziedzictwa w Szczekocinach ${ }^{30}$. Dwa dni później przyznali sporne nieruchomości klasztorowi miechowskiemu ${ }^{31}$. Dnia 1 października 1398 r. królowa Jadwiga akceptowała zbycie wsi Koszycka Wola przez Piotra, syna Szymona, podsędkowi ${ }^{32}$. W tym samym dniu Michał i Dobiesław rozpatrywali sprawę wadium z tytułu poręki ${ }^{33}$. Dnia 10 grudnia $1398 \mathrm{r}$. obaj zaświadczali kolejne nabycie dóbr przez prepozyta i konwentu w Miechowie ${ }^{34}$. W dniu 7 lutego 1399 r. wyrokował (wraz z sędzią Michałem) w sprawie obiektów we wsi biskupiej Gruszów ${ }^{35}$. Dnia 17 lutego 1399 r. jako Dobek z Koszyc, podsędek, świadkował na dokumencie Władysława II Jagiełły przenoszącym kościelną wieś Dojazdów z prawa polskiego na magdeburskie ${ }^{36}$. W dniu 7 marca 1399 r. Dobcone de Cosczycze jako podsędek krakowski świadkował na nadaniu dla kościoła tarnowskiego przez Jana z Tarnowa ${ }^{37}$. Dnia 24 marca 1399 r. Michał i Dobiesław zaświadczali kolejne nabycie dóbr przez prepozyta i konwentu w Miechowie $^{38}$. W dniu 10 maja 1399 r. zajmowali się rozgraniczeniem dóbr rycerskich i klasztornych w kontekście zakazu ich naruszania ${ }^{39}$. Dnia 13 maja 1399 r. sędzia Michał i podsędek Dobiesław zatwierdzili sprzedaż młyna w Swoszowicach ${ }^{40}$. W dniu 17 lipca 1399 r. orzekali w sprawie nagany szlachectwa ${ }^{41}$. Dnia 26 sierpnia 1399 r. zajmowali się nabyciem dóbr rycerskich ${ }^{42}$. W dniu 30 października 1399 r. zajmowali się nadaniem dla klasztoru w Koprzywnicy ${ }^{43}$. Dnia 28 lipca 1400 r. obaj zaświadczyli, że Małgorzata, wdowa po Stefanie, zwanym Pęcherzem,

\footnotetext{
${ }^{28}$ SPPP, T. 8, cz. 2, nr 7221 (s. 515).

${ }^{29}$ SPPP, T. 8, cz. 2, nr 7222 (s. 515).

${ }^{30}$ DSZK, nr 74 (s. 81).

${ }^{31}$ DSZK, nr 75 (s. 82).

${ }^{32}$ KDKK, T. 2, nr CCCCXXX (s. 225).

${ }^{33}$ DSZK, nr 76 (s. 84).

${ }^{34}$ DSZK, nr 77 (s. 85).

${ }^{35}$ KDKK, T. 2, nr CCCCXXXIV (s. 230). Podobnie dalej - 9 maja 1399 r., nr CCCCXXXVIII (s. 236).

${ }^{36} \mathrm{KDKK}, \mathrm{T} .2$, nr CCCCXXXV (s. 232).

37 AS, T. 2, nr LXXVIII (s. 92).

38 DSZK, nr 78 (s. 86).

${ }^{39}$ DSZK, nr 79 (s. 87).

${ }^{40}$ KDKK, T. 2, nr CCCCXXXIX (s. 237). Podobnie dalej - 13 kwietnia 1401 r., nr CCCCLI (s. 252). Inna sprawa dot. Swoszowic z 14 lutego 1402 r., nr CCCCLVIII (s. 263). Kolejna z 9 kwietnia 1404 r., nr CCCCLXXXI (s. 296). Inne nadanie z 6 kwietnia 1408 r., nr DIV (s. 322).

${ }^{41}$ DSZK, nr 80 (s. 88).

${ }^{42}$ DSZK, nr 81 (s. 90). Dokument ten omawiam w pracy Panowie z Grodziny herbu Szreniawa. Analiza historycznoprawna [w druku].

${ }^{43}$ DSZK, nr 82 (s. 91).
} 
dziedzicu Rzeszotar, sprzedała te dobra Andrzejowi Czarniszy, landwójtowi wyższego sądu prawa niemieckiego na zamku krakowskim ${ }^{44}$. W dniu 19 sierpnia 1400 r. rozpatrzyli spór odnoszący się do prawa niemieckiego ${ }^{45}$. Dnia 11 października 1400 r. obaj poświadczyli, że dwie osoby z Sędziszowa: dziedzic Andrzej i proboszcz Dziersław zawarli układ dotyczący miejscowej karczmy ${ }^{46}$. W dniu 9 listopada 1400 r. Michał i Dobiesław zaświadczyli, iż Paszek z Biskupic dokonał jednania $\mathrm{z}$ Pietraszem Zabawskim z Faliszowic w sprawie dopływu wody do młyna tego ostatniego ${ }^{47}$. Dnia 17 listopada 1400 r. sędzia i podsędek poświadczyli wymianę dóbr między kasztelanem krakowskim Janem z Tęczyna a prepozytem w Staniątkach ${ }^{48}$. W dniu 5 lutego 1401 r. zatwierdzili kolejne nabycie dóbr przez prepozyta i konwent miechowski ${ }^{49}$. Dnia 11 maja 1401 r. zaświadczyli kontrakt w sprawie Parkoszowic ${ }^{50}$. W 1401 r. Dobiesław, podsędek krakowski, gwarantował Klemensowi ze Strzeszkowic zwrot do św. Mikołaja (6 grudnia) 30 grzywien kwartników wwiązaniem do czterech kmieci w Konarach płacących cztery grzywny czynszu ${ }^{51}$. W dniu 10 maja 1402 r. Michał i Dobiesław poświadczyli umowę dwóch klasztorów o korzystanie z wody rzeki Dłubni ${ }^{52}$. Równolegle zaświadczyli, że prepozyt miechowski (w imieniu konwentu) podzielił się wsią Wola z Heleną, żoną Mikołaja, niegdyś z Łukomy, teraz dziedzica Woli $^{53}$. Następnego dnia poświadczyli, iż Klemens z żoną Katarzyną, dziedzice Luszowic sprzedali rolę za 30 grzywien Piotrowi, dziedzicowi w Wilczkowicach ${ }^{54}$. W dniu 30 maja 1402 r. zaświadczyli kolejne odstąpienie dóbr klasztorowi miechowskiemu $^{55}$. Dnia 29 sierpnia 1402 r. zaświadczyli, że Jan, dziedzic ze Swoszowic, sprzedał część wsi Janowi, proboszczowi w kościele Bożego Ciała na Kazimierzu $^{56}$. W dniu 1 października 1402 r. zaświadczyli, że Wierzbięta z Branic darował krakowskiemu klasztorowi Dominikanów łąki nad Wisłą we wsi Szczurów ${ }^{57}$. Dnia 9 października 1402 r. zaświadczyli kolejny kontrakt w Parko-

${ }^{44}$ DSZK, nr 83 (s. 92).

45 DSZK, nr 84 (s. 93).

46 DSZK, nr 85 (s. 94).

${ }^{47}$ DSZK, nr 86 (s. 95).

${ }^{48}$ DSZK, nr 87 (s. 95).

${ }^{49}$ DSZK, nr 88 (s. 96).

${ }^{50}$ DSZK, nr 89 (s. 97).

${ }^{51}$ http://www.slownik.ihpan.edu.pl/search.php?id=7828 [dostęp: 13.10.2018].

${ }^{52}$ DSZK, nr 90 (s. 98).

${ }^{53}$ DSZK, nr 91 (s. 99).

${ }^{54}$ DSZK, nr 92 (s. 100).

${ }^{55}$ DSZK, nr 93 (s. 101). Dalsze z 11 grudnia 1402 r., DSZK nr 98 (s. 106). Kolejne z 22 grudnia 1402 r., nr 99 (s. 107). 10 maja 1403 r., nr 103 (s. 111). 29 maja 1403 r., nr 104 (s. 112). 11 czerwca 1403 r., nr 105 (s. 113). 2 stycznia 1404 r., nr 107 (s. 115). 1 października 1404 r., nr 111 (s. 120). 3 października 1404 r., nr 113 (s. 121). 9 maja 1408 r., nr 127 (s. 136).

${ }^{56}$ DSZK, nr 94 (s. 102). Inne poświadczenie z 21 listopada 1402 r., nr 97 (s. 105).

${ }^{57}$ DSZK, nr 95 (s. 103). 
szowicach $^{58}$. Dnia 3 stycznia 1403 r. poświadczali dwa razy sprawę dóbr w Chomranicach $^{59}$. W dniu 23 stycznia 1403 r. zaświadczyli zbycie trzeciej części młyna i karczmy ${ }^{60}$. Dnia 4 października 1403 r. Michał, sędzia, i Dobiesław, podsędek, zatwierdzili nadanie dóbr przez Mikołaja z Jodłownika szczyrzyckim cystersom ${ }^{61}$. Dnia 13 grudnia 1403 r. zaświadczyli, iż Piotr, dziedzic z Unikowa zastawił za 25 grzywien szerokich groszy praskich i 5 grzywien kwartników swą część wsi Mikołajowi, dziedzicowi z Klęczan ${ }^{62}$. W 1403 r. Baryczka, rządca z Łysakowa, nie stawił się przeciw podsędkowi krakowskiemu Dobiesławowi z Koszyc i Konarów w powiecie pilzneńskim i o zabranie kmieciom z Łysakowa pięciu siekier i dwóch motyk na wspólnej dziedzinie (communi hereditate) ${ }^{63}$. W dniu 19 lutego 1404 r. nowy sędzia Tomasz i podsędek Dobiesław poświadczyli, iż Andrzej, dziedzic Potoku, sprzedał za 16 grzywien swą karczmę z rolami opatowi Jakubowi i konwentowi jędrzejowskiemu ${ }^{64}$. Dnia 27 maja 1404 r. rozpatrywali sprawę oczyszczenia szlachectwa ${ }^{65}$. W dniu 2 października 1404 r. badali ważność dokumentu $^{66}$. Dzień później zajmowali się długami Piotra Rożna ${ }^{67}$. Dnia 2 grudnia 1404 r. zaświadczali zamianę dóbr ${ }^{68}$. Dnia 24 lutego 1405 r. Jan z Tęczyna, kasztelan i starosta krakowski, i podsędek Dobiesław rozpatrywali sprawę długu 11 grzywien kwartników Pełki z Grzegorzowic wobec Helwiga z Przybysławic ${ }^{69}$. W dniu 17 marca 1405 r. ci sami zaświadczali zbycie dóbr klasztorowi miechowskiemu $^{70}$. Dnia 1 października 1405 r. nowy sędzia Jan z Oleśnicy i Dobiesław zaświadczyli, że Izrael, Kanaan i Abraham, synowie Lewka, sprzedali dom w Krakowie wojewodzie krakowskiemu Janowi z Tarnowa za 80 grzywien $^{71}$. W dniu 3 października 1405 r. Dobiesław (z Koszyc, pow. Pilzneński), podsędek krakowski, i Mściszek Ksiąski (z Konaszówki) zawarli układ małżeński. Mściszek wydać miał za mąż za jego syna Dobka (z Konarów) swą wnuczkę (wnukam) Włodkę (czyli Elżbietę, córkę Włodka z Konaszówki), a Dobiesław uczynić miał Mściszka opiekunem i obrońcą w swych dobrach dziedzicznych. Mściszek miał

${ }^{58}$ DSZK, nr 96 (s. 104).

${ }^{59}$ DSZK, nr 100-101 (s. 108-109).

${ }^{60}$ DSZK, nr 102 (s. 110).

${ }^{61}$ KDP, T. 3, nr CLXXXVII (s. 365). Inna sprawa z 19 stycznia 1406 r., DSZK, nr 119 (s. 128), nr 120 (s. 129), nr 121 (s. 130). 17 stycznia 1408 r., nr 126 (s. 135). 12 maja 1408 r., nr 128 (s. 137).

${ }^{62}$ DSZK, nr 106 (s. 114). Dalej z 10 stycznia 1404 r., nr 108 (s. 116).

${ }^{63} \mathrm{http} / / / \mathrm{w} w w$. slownik.ihpan.edu.pl/search.php?id=25381 [dostęp: 13.10.2018].

${ }^{64}$ DSZK, nr 109 (s. 117). Podobnie 15 grudnia 1405 r., nr 118 (s. 127).

${ }^{65}$ DSZK, nr 110 (s. 118).

${ }^{66}$ DSZK, nr 112 (s. 121).

${ }^{67}$ DSZK, nr 114 (s. 122).

${ }^{68}$ DSZK, nr 115 (s. 124).

${ }^{69}$ KDKK, T. 2, nr CCCCLXXXV (s. 299). Orzeczenie z 15 listopada 1407 r. Jana z Oleśnicy i Dobiesława nr DII (s. 321).

${ }^{70}$ DSZK, nr 116 (s. 125).

${ }^{71}$ DSZK, nr 117 (s. 126). 
trzymać swe dobra w dożywociu, a po śmierci obaj mieli przekazać swe dobra wnukom. Mściszek zobowiązał się dotrzymać układu pod zakładem 100 grzywien $^{72}$. W 1405 r. podsędek wystąpił przeciw Piotraszowi, rządcy z Łysakowa, o zadanie siedmiu krwawych ran $^{73}$. Dnia 11 marca 1406 r. Jan, sędzia, i Dobiesław, podsędek, ogłosili dekret Władysława II Jagiełły dla miasta Śrem ${ }^{74}$. Dnia 10 maja 1406 r. obaj przyznali prawo własności klasztorowi w Mogile ${ }^{75}$. W dniu 13 maja 1406 r. Dobiesław z Koszyc jako podsędek wraz z sędzią Janem z Oleśnicy zajmowali się sporem między kupcami krakowskimi i lwowskimi handlującymi z Tatarami i Wołochami ${ }^{76}$. Dnia 3 listopada 1406 r. Dobiesław świadkował na dokumencie kasztelana i starosty krakowskiego Jana z Tarnowa (zatwierdzenie kontraktu) $^{77}$. W 1406 r. Mikołaj, proboszcz z Książa Małego, sądził się z Elżbietą, żoną Dobiesława z Konarów, o dziedzinę w Książu Małym zastawioną przez Piotra z Książa Małego, za którą on zapłacił pieniądze. Zawarli ugodę ${ }^{78}$. Dnia 26 czerwca 1408 r. Dobiesław z Koszyc jako podsędek wraz z sędzią Janem z Oleśnicy zaświadczyli, iż Pietrasz z Kamienia, wraz z żoną Małgorzatą oraz teściową Hanką sprzedali za 500 grzywien wieś Kamień prepozytowi Konradowi i konwentowi kanoników regularnych Bożego Ciała na Kazimierzu $^{79}$. W dniu 19 grudnia 1408 r. ci sami zatwierdzili kontrakt między Dersławem ze Zdziesławic a wspomnianym już Helwigiem z Przybysławic ${ }^{80}$. W 1408 r. Jakusz z Częstoszowic oświadczył, że pozywający go Dobek (z Konarów parafia Nawarzyce i z Koszyc w pow. Pilzneńskim), podsędek krakowski, nie miał nic na prawie dziedzicznym w Konaszówce, Głogowianach i Częstoszowicach $^{81}$. Dnia 4 lutego 1409 r. Dobiesław z Koszyc jako podsędek wraz z sędzią Janem z Oleśnicy orzekali w sprawie nabycia dóbr przez Jana z Tarnowa, kasztelana krakowskiego ${ }^{82}$. Ostatni raz Dobiesław występował jako osoba żyjąca 27 sierpnia 1409 r., gdy z Janem z Oleśnicy zatwierdzali zbycie dóbr Leńcze przez sołtysa w Lechowie Franczka Annie, żonie Jana Coibera ${ }^{83}$.

${ }^{72}$ Starodawne prawa polskiego pomniki z ksiag rękopiśmiennych dotąd nieużytych główniej zaś z ksiag dawnych sądowych ziemskich i grodzkich ziemi krakowskiej. Wyciągnął i wydał A.Z. Helcel. T. 2. Kraków 1870, cyt. dalej: SPPP, T. 2, nr 1108 (s. 165).

${ }^{73} \mathrm{http}: / / w w w . s l o w n i k . i h p a n . e d u . p l / s e a r c h . p h p ? i d=25381$ [dostęp: 13.10.2018].

${ }^{74}$ Kodeks dyplomatyczny Polski. T. 1. Red. L. Rzyszczewski. Warszawa 1847, cyt. dalej: KDP, T. 1, nr CLVI (s. 278).

${ }^{75}$ DSZK, nr 122 (s. 131). Podobnie: DSZK nr 123 (s. 132). 4 X 1407 r., nr 124 (s. 133).

${ }^{76}$ KDMK, cz. 1, nr CVIII (s. 153).

${ }^{77}$ KDKK, T. 2, nr CCCCXCIII (s. 310).

${ }^{78} \mathrm{http}: / /$ www.slownik.ihpan.edu.pl/search.php?id=8477 [dostęp: 13.10.2018].

${ }^{79}$ KDKK, T. 2, nr DXI (s. 331) = DSZK, nr 129 (s. 137). Podobnie 12 sierpnia 1408 r., KDKK, T. 2, nr DXII (s. 332).

${ }^{80}$ KDKK, T. 2, nr DXVI (s. 335).

${ }^{81}$ http://www.slownik.ihpan.edu.pl/search.php?id=7830 [dostęp: 13.10.2018].

${ }^{82}$ AS, T. 2, nr XCVII (s. 115).

${ }^{83}$ KDKK, T. 2, nr DXX (s. 339). 


\section{5-8. Dobiesław, Ścibor i Jan Rokosz oraz Anna}

W latach 1414-1428 występował Dobiesław z Konarów i Koszyc, syn Dobiesława z Koszyc i Konarów, podsędka krakowskiego, herbu Ostoja, zmarły w 1431-1432 r., brat Ścibora z Koszyc i Jana Rokosza z Koszyc ${ }^{84}$. W 1415 r. Elżbieta, żona Dobiesława z Konarów (Młodszego, syna podsędka), sprzedała za 600 grzywien Mikołajowi Morawcowi z Ossowic połowę wsi Głogowiany i całą część w Konaszówce z prawem patronatu kościoła, scholasterii i szkoły w Książu Wielkim. Jakusz z Częstoszowic zakwestionował sprzedaż, a Mikołaj Morawiec i jego żona Katarzyna gwarantowali Elżbiecie i Dobiesławowi spłatę 240 grzywien ewentualnym wwiązaniem w połowę Głogowian i w całą część Konaszówki ${ }^{85}$. W 1415 r. Katarzyna, córka Włodka z Konaszówki, pierwsza żona Mikołaja Morawca, z racji prawa bliższości wykupiła za 90 grzywien zastawioną Jakubowi z Burzenina w ziemi sieradzkiej całą część dóbr jej siostry Elżbiety, żony Dobiesława z Konarów w Konaszówce i Głogowianach ${ }^{86}$. W 1416 r. Elżbieta i jej siostra Katarzyna, córki Włodka z Konaszówki, podzieliły dobra. Działowi podlegały: dziedziny i role należące do dworu w Konaszówce, Głogowiany z wszystkimi przynależnościami, dwie łąki leżące na końcu gaju Olszyny (dziś w Rzędowicach pole zwane Olszyny), obok ról Pawła proboszcza w Książu Wielkim, role położone wyżej po prawej stronie drogi do Małoszowa, koło drogi krakowskiej, z wyłączeniem wszystkich gajów należących do Częstoszowic, łan niegdyś sołtysa w Konaszówce, koło ściegny służącej do pędzenia bydła, dwa ogrody z zagrodnikami na przedmieściu Książa, role w Konaszówce należące dawniej i teraz do dworu w Konaszówce, połowa dąbrowy między Wolicą (parafia Książ Wielki) a Radziczowem (dziś nie istnieje), przynależnej do połowy wsi Głogowiany. Działowi podlegają też kmiecie w Konaszówce: Rytowa, Wojciech Krzywonos, Florian Płaczkowic, Baldanowa, Franek syn krawca, Mikołaj Dąbek, Wawrzyniec Laszek, Jan Kochan, Maciej Patek, Klimek Kramarzowski, Kotanowa (Kochanowa?). Młyn w Częstoszowicach miał należeć do obu sióstr, mianowicie połowa do dworu w Konaszówce, połowa do wsi Częstoszowice. Wrochna, mniszka (trzecia z sióstr), miała otrzymywać 3 grzywny czynszu ${ }^{87}$. W 1422 r. Dobek z Konarów i Piotr Kot ze Zdzisławkowic (ówczesny pow. Wiślicki) poręczyli Mikołajowi ze Zbigniewa (dziś Zbydniów) spłatę 260 grzywien przez Marcina z Kamieńca, ten ostatni gwarantował Piotrowi i Dobkowi, że w razie niespłacenia tej sumy udzielić miał Mikołajowi wwiązanie do swych dóbr Moskorzów, Chlewska Wola, Jaroniowice. Dobek ręczył zaś Piotrowi za Marcina, że za 300 grzywien ustąpi on z dóbr Bukownik, Komorniki, Wolica

\footnotetext{
${ }^{84} \mathrm{http}: / /$ www.slownik.ihpan.edu.pl/search.php?id=7828 [dostęp: 13.10.2018].

${ }^{85} \mathrm{http}: / /$ www.slownik.ihpan.edu.pl/search.php?id=7830 [dostęp: 13.10.2018].

${ }^{86} \mathrm{http}: / / \mathrm{www}$. slownik.ihpan.edu.pl/search.php?id=7830 [dostęp: 13.10.2018].

$87 \mathrm{http}: / /$ www.slownik.ihpan.edu.pl/search.php?id=7830 [dostęp: 13.10.2018].
} 
i Niezdów i wniesie zapis do księgi ziemskiej, a wówczas Piotr zwolni Dobka z poręki ${ }^{88}$. W 1427 r. Marcin z Kamieńca pozwał Dobka z Konarów o 300 grzywien poręki, złożonej za niego przez tegoż Dobka i ubezpieczonej na wsiach Niezdów, Bukownik, Komorniki i Wolica, których w sądzie nie oddał do dyspozycji Piotra Kota i nie zapisał mu ich zgodnie z poręką. Marcin miał złożyć podwójną przysięgę w sprawie z braćmi Mikołajem z Moskorzowa, kanonikiem krakowskim, i Klemensem o połowę swych dóbr dziedzicznych i o ruchomości. Marcin miał również złożyć podwójną przysięgę w sprawie z Mikołajem z Chlewic o dokument wójtowski i wójtostwo w mieście Wielopolu (pow. pilzneński) i o 300 grzywien kary. Piotr Kot z Kotek, przedkładając dokument Mikołaja z Michałowa, wojewody sandomierskiego i starosty krakowskiego, pozyskał na poręczycielu Dobku z Konarów 300 grzywien poręki ubezpieczonej na Niezdowie, Bukowniku, Komornikach i Wolicy, złożonej mu przez niego za Marcina z Kamieńca, gdyż Marcin wbrew tej poręce nie przekazał Piotrowi sądownie tych dóbr ${ }^{89}$. Dnia 3 listopada 1432 r. Nieustęp, opat jędrzejowski, miał zapłacić sześć skojców Elżbiecie, wdowie po Dobku z Konarów i tyleż samo Tomkowi woźnemu sądowemu za „wstecz” z tytułu krzaków leszczyny ${ }^{90}$. W 1435 r. Elżbieta, wdowa po Dobiesławie z Konarów, nie stawiwszy się w sądzie, przegrała proces ze wspomnianym już Mikołajem Morawcem z Konaszówki o części w tej wsi i Częstoszowicach o wartości 1000 grzywien, pozostałą po zmarłej siostrzenicy Katarzynie i o karę 100 grzywien za przeoranie siłą ról ${ }^{91}$. W 1436 r. Elżbieta, wdowa po Dobiesławie z Konarów oświadczyła, że Mikołaj Morawiec wypłacił jej 340 grzywien za połowę dziedziny w Częstoszowicach i zastawił za 140 grzywien Elżbiecie całą część w Mironicach, którą sam dzierżył zastawem oraz gwarantował jej spłatę 260 grzywien wwiązaniem do części swych dóbr z czynszem sześciu grzywien ${ }^{92}$.

W 1444 r. Mikołaj z Mokrska zapłacił karę ,pietnadziesta” Annie z Konarów, żonie Stanisława z Lipia, i drugą sądowi, gdyż pozwał kobietę pozwem opieczętowanym pieczęcią ziemi sandomierskiej. Pozwał też „czcigodnego” (strenuus) Niemstę, sędziego grodzkiego krakowskiego, za założenie na niego pamiętnego w sporze z Anną. Niemożliwe jest, by była to siostra poprzednio wymienionej trójki, bo Mikołaj został zobowiązany pokazać dokumenty większej sprawy Janowi Rokoszowi z Koszyc, podstarościemu krakowskiemu ${ }^{93}$. Dnia 28 kwietnia 1444 r. toczył się spór między Nieustępem, opatem jędrzejowskim,

${ }^{88} \mathrm{http}: / /$ www.slownik.ihpan.edu.pl/search.php?id=7817 [dostęp: 13.10.2018].

${ }^{89} \mathrm{http}: / / \mathrm{www}$. slownik.ihpan.edu.pl/search.php?id=7817 [dostęp: 13.10.2018].

${ }_{90}$ SPPP, T. 2, nr 2415 (s. 366).

${ }^{91}$ http://www.slownik.ihpan.edu.pl/search.php?id=7830 [dostęp: 13.10.2018].

$92 \mathrm{http}: / /$ www.slownik.ihpan.edu.pl/search.php?id=7830 [dostęp: 13.10.2018].

${ }^{93}$ F. Sikora: Mokrsko Dolne i Górne. W: Słownik historyczno-geograficzny województwa krakowskiego w średniowieczu. Red. W. Bukowski. T. 4, z. 4. Kraków 2014, s. 785 (lewa szpalta). 
reprezentowanym przez Jana Ossowskiego, a Anną z Konarów, reprezentowaną przez Macieja Szczedrcowskiego, udziałem notariusza grodzkiego. Sąd zasądził na rzecz Anny 4 grzywny pospolitej monety, płatne w dwa tygodnie oraz karę „pietnadziesta”, a także analogiczne kary dla sądu ${ }^{94}$. W dniu 7 lipca 1444 r. Anna z Konarów przyprowadziła do sądu sześciu świadków w celu złożenia przysięgi, że wiedzieli o fakcie napadu dokonanego przez Mikołaja Mokrskiego z Michowa z 14 pomocnikami na jej dziedzinę, przy czym zabrali gwałtem kmiecia Michała i go uprowadzili oraz o wyrządzenie szkód na 20 grzywien (jże Micolaj Mocrsky alias Smichowa, przigechaw nadzedzyna do Anny do Conar gwaltownye sgego pomoczniky cztermanaczczoma, wsyal gey Michala kmyecza gwaltownye, a wyodl gy kdze chczal: a uskodzil ya dwadzesszcza grziwen $)^{95}$. Poprzednia sprawa ciągnęła się jeszcze w dniu 19 sierpnia $1444 \mathrm{r}$. Sąd grodzki wyznaczył termin na przesłuchanie „czcigodnych”: Jana Rokosza, podstarościego krakowskiego (piercy), i Mikołaja Mokrskiego (sąpierza). Jan Rokosz zamierzał się oczyścić przed sędzią-komisarzem Stanisławem ze Złotej (powołał go regent Królestwa Jan z Czyżowa, kasztelan i starosta krakowski). Mikołaj z kolei pozwał Jana Rokosza. Pierwszy przyprowadził Piotra Gagata (z Knyszyna - komentarz T.K.), który twierdził, że sprawa Mikołaja była większa (o 200 grzywien) i toczyła się przed Janem Górskim, sędzią starosty chęcińskiego z Borkiem z Woli (współpiercą? - komentarz T.K.). Jan Rokosz zwrócił jednak uwagę, że sprawa o godność była więcej warta niż 200 grzywien. Ideo interrogatur si juste disponsit vel non ${ }^{96}$.

\section{Część druga. Ród herbu Szreniawa}

\section{Marcin}

Marcinem z Grodziny zajmuję się w innej publikacji ${ }^{97}$. Jak tam wspomniano, był synem Przybka i bratem Piotra z 1360 r. Marcin był - to jest raczej pewne - ojcem Marcisza, Mikołaja i prawdopodobnie Peterlina=Piotra.

\footnotetext{
94 SPPP, T. 2, nr 3206 (s. 540).

${ }_{95}$ SPPP, T. 2, nr 3212 (s. 541).

${ }^{96}$ SPPP, T. 2, nr 3214 (s. 541).

${ }_{97}$ T. Kruszewski: Panowie z Grodziny herbu Szreniawa...
} 


\section{Marcisz (Marcin)}

W latach 1376-1400 występował Marcisz z Grodziny i Konarów, brat kasztelana w Konarach Mikołaja ${ }^{98}$. Marcisz z Konarów i Grodziny był — zdaniem Janusza Kurtyki — bratem Mikołaja, ale i Peterlina=Piotra ${ }^{99}$. Ci zaś — ten domysł jest prawie pewnikiem - synami wspomnianego wyżej Marcina z Grodziny. Pojawia się 17 marca 1376 r., gdy Tomek z Chotlic miał z nim termin peremptoryjny ${ }^{100}$. Dnia 1 kwietnia tego samego roku sądził się już z obu braćmi Marciszem i Mikołajem o wyręb drzew (pro poraba $[$ sic! $])^{101}$. Dnia 1 kwietnia 1376 r. Tomek z Kotlic miał sprawę o porębę (pro poraba) z Marcinem i Mikołajem z Grodziny ${ }^{102}$. Między 12 a 19 czerwca tego roku sąd nakazał Marciszowi zapłacić 6 grzywien Tomkowi ${ }^{103}$. W dniu 6 października 1388 r. sąd wyznaczył drugi termin na św. Marcina jako peremptoryjny w sprawie Peterlina ze Szczytnik z braćmi (Mikołajem), kasztelanem de Conari i Marciszem ${ }^{104}$. Dnia 4 lutego 1396 r. Imramowa Włostowska zgłosiła sprzeciw w sprawie z Marczissio de Grzodzina, wspartego przez tamtejszego proboszcza Stanisława, a chodziło o niebagatelną sumę 70 grzywien $^{105}$. Dnia 30 września 1396 r. Marcisz z Grodziny zwolnił wdowę po Jurze z Włostowic i jej dzieci z obowiązku zapłacenia jego żonie 60 grzywien wiana ${ }^{106}$. W dniu 10 lutego 1400 r. Paszko z Bedlna miał dwie sprawy: pierwszą z Przybkiem z Grodziny (herbu Szreniawa) (drugi termin) o 5 grzywien, drugą aż o 50 grzywien z Marciszem ${ }^{107}$.

${ }^{98} \mathrm{http}: / /$ www.slownik.ihpan.edu.pl/search.php?id=6193 [dostęp: 13.10.2018].

${ }^{99} \mathrm{http}: / / w w w . s l o w n i k . i h p a n . e d u . p l / s e a r c h . p h p ? i d=7828$ [dostęp: 2.08.2017].

100 Starodawne prawa polskiego pomniki. T. 8: Antiquissimi libri iudiciales terrae cracouiensis. Pars I: Ab an. 1374-1390. Editionem curauit B. Ulanowski. Cracoviae A. MDCCCLXXXIV, cyt. dalej: SPPP, T. 8, cz. I, nr 46 (s. 3).

101 SPPP, T. 8, cz. 1, nr 81 (s. 5).

102 SPPP, T. 8, cz. 1, nr 81 (s. 5).

${ }^{103}$ SPPP, T. 8, cz. 1, nr 270 (s. 12).

104 SPPP, T. 8, cz. 1, uw. CXXII (nr 15, s. 280).

${ }^{105}$ Ksiega ziemska krakowska 2. 1394-1397. Wyd. W. Bukowski, M. Zdanek. Warszawa 2012, cyt. dalej: KZK2, nr 3848 (s. 257).

${ }^{106}$ SPPP, T. 8, cz. 2, nr 5759 (s. 379).

107 SPPP, T. 8, cz. 2, uwaga CCCXV (nr 13 i 14, s. 821). Następne terminy obu tych spraw były 24 II 1400 r., uwaga CCCXVII (nr 4 i 5, s. 829-830). Paszko z Bedlna wydaje się tożsamy z Paszkiem z Lanckorony, który 23 marca 1400 r. dalej sądził z Przybkiem i Marciszem, uwaga CCCXXI (nr 38 i 39, s. 841). 


\section{Mikolaj}

W latach 1376-1394 występował Mikołaj, Miczek Konarski z Konarów i Grodziny, kasztelan konarski, brat Marcisza i Peterlina=Piotra ${ }^{108}$. Mikołaj z Grodziny i Konarów był już wspominany wyżej. W dniu 17 marca 1376 r. Tomek z Kotlic miał termin peremptoryjny z Mikołajem z Grodziny ${ }^{109}$. Ponadto 22 kwietnia 1376 r. Mikołaj z Grodziny uniknął Burnosum (jakiś człowiek), o co został przez niego pozwany ${ }^{110}$. Dnia 6 stycznia 1386 r. Mikołaj z Grodziny miał przedłożyć w sądzie dokument w sporze z Budkiem z Opatkowic o kmiecia zbiegłego do Opatkowic ${ }^{111}$. Dnia 31 grudnia 1386 r. Janek, pełnomocnik (procurator) Zbyszka z Lubczy, sądził się z Mikołajem z Konarów o Wolę ${ }^{112}$. Dnia 7 stycznia 1390 r. Miczek z Grodziny został ukarany karą ,siedemdziesiąt” na rzecz Katuszy z Krakowa, której miał zapłacić 2 grzywny, do czego był zobowiązany wyrokiem ${ }^{113}$. Kolejny raz występował 8 kwietnia 1392 r. $^{114}$. W 1394 r. Michał z Proszowic pozwał Mikołaja i jego bratanka? Jakuba z Konarów o zabór pszenicy. W tym samym roku Mikołaj z (bliżej nieokreślonym) synem z Konarów winien stawić kapelana Jana z Niegardowa w sprawie z Markiem z Bojańczyc. Jeszcze w tym roku Wojciech z Brzeska z kapelanem Gotfrydem z Brzeska miał stawić w sądzie komornika Wojciecha z Brzeska przeciwko wojewodzie (kasztelanowi? - domysł J. Kurtyki) z Konarów ${ }^{115}$. Jak już wspomniano wyżej, Mikołaj był w 1388 r. kasztelanem w Konarach, wnioski jednak, jakie wyciągnął z tego faktu Franciszek Sikora (po części też Janusz Kurtyka), są niezrozumiałe. Kasztelan w Konarach oznacza to samo, co kasztelan konarski, ale jako przymiotnik od miejscowości. Konarski jako urząd pochodzi od słowa koń i oznacza koniuszego $^{116}$. Taki „konarski” istniał w Krakowie. Wciąż jednak nie ustalono bliżej daty zaginięcia urzędu konarskiego krakowskiego. Na pewno 17 sierpnia 1372 r. piastował go - zmarły w 1379 r. - Klemens z Nasiechowic, herbu Gryf $^{117}$. Zachowane źródła urząd ten opisywały w trzech dzielnicach - kujawskiej, łęczyckiej i sieradzkiej, który przekształcał się z wyjściowego urzędu nadwornego monarchy w dygnitarski, tytułowany kasztelanem konarskim. Pominę tu dalsze dywagacje Franciszka Sikory, który sam wpędził się w kłopoty, zamieniając kasztelana w Konarach w konarskiego, bo ten drugi urząd pełniły

\footnotetext{
${ }^{108} \mathrm{http} / /$ www.slownik.ihpan.edu.pl/search.php?id=7828 [dostęp: 2.08 .2017 ].

109 SPPP, T. 8, cz. 1, nr 46 (s. 3).

110 SPPP, T. 8, cz. 1 , nr 126 (s. 7).

111 SPPP, T. 8, cz. 1, nr 3947 (s. 172).

112 SPPP, T. 8, cz. 1, uwaga XXXVI (nr 12, s. 208).

${ }^{113}$ SPPP, T. 8, cz. 1, nr 5483 (s. 360).

$114 \mathrm{http}: / /$ www.slownik.ihpan.edu.pl/search.php?id=6193 [dostęp: 13.10.2018].

$115 \mathrm{http}: / /$ www.slownik.ihpan.edu.pl/search.php?id=7828 [dostęp: 2.08.2017].

116 J. Bardach: Historia państwa i prawa Polski. T. 1: Do połowy XV wieku. Warszawa

${ }^{117}$ KDMłp, T. III. 1333-1386. Wyd. F. Piekosiński. Kraków 1887, nr DCCCL (s. 261).
} 1973, s. 455. 
w tym czasie inne osoby i Mikołaj jako konarski nigdzie nie pasował ze względów chronologicznych ${ }^{118}$. Sprawa jest jeszcze bardziej zagmatwana, bo Zbigniew Kaczmarczyk, zajmujący się kasztelanami konarskimi, poruszył także zagadnienie nazwy miejscowości „Konary”, którą traktował jako pochodzącą od koniuszego, czyli konarskiego, i były to osady służebne, którymi jednak zarządzał kasztelan krakowski ${ }^{119}$. Jedno jest pewne: kasztelan w Konarach to nie konarski.

W latach 1394-1401 była odnotowana Dorota, wdowa po Mikołaju z Konarów i Grodziny, kasztelanie. Pojawiła się 3 lutego 1394 r., gdy Jakusz z Tczycy miał stawić przed sądem Jakusza ongiś z Lubczy (ówczesny pow. ksiąski) przeciw (Dorocie) wdowie po Mikołaju z Grodziny o 34 grzywny długu i 19 grzywien kary ${ }^{120}$. Dnia 30 września 1394 r. na wiecu Przybek z Grodziny miał termin z panią z Konarów i jej trzema synami: Janem, Piotrem i Zawiszą ${ }^{121}$. Tego samego dnia Domina Konarzska sądziła się z Jakuszem z Tczycy. Ten przeciwko niej przyprowadził do sądu Bartłomieja, proboszcza z tej wsi, który złożył zeznanie, że Jakuszowi należało się 30 grzywien długu i 16 kolejnych odsetek $^{122}$. W 1394 r. Dorota, wdowa z Konarów, oświadczyła, że Pietrasz z braćmi (niejasne, Mikołaj miał tylko dwóch braci, jeszcze Marcisza - T.K.) winni byli wypłacić jej 15 grzywien z racji posagu i dopiero wtedy uzyskać mieli od niej dobra tytułem prawa bliższości ${ }^{123}$. W 1394 r. Mikołaj z Brzuchani wystąpił przeciw (Dorocie - dopisek T.K.) wdowie po Mikołaju z Grodziny o 12 źrebiąt, 12 świń i dziedzinę w Zegartowicach ${ }^{124}$. Dnia 4 lutego 1396 r. Jakusz z Tczycy był w sporze na wiecu z panią z Konarów ${ }^{125}$. W dniu 1 października 1397 r. Stanisław i Jaszek z Ławszowa mieli sprawy z dominam de Conari. W swojej sprawie Jaszek dostarczył do sądu pismo od królowej ${ }^{126}$. Dnia 2 października 1397 r. Przybek z Grodziny procesował się z panią z Konarów i (jej) synami ${ }^{127}$. W dniu 5 lutego 1398 r. Przybek z Grodziny miał termin na wiec przeciw Dorocie (wdowie po Mikołaju z Grodziny) i jej synom: Janowi, Piotrowi i Zawiszy z Konarów o 300 grzywien i o pieczęć cre $^{28}$. Tego też dnia Dorota (wdowa po Mikołaju) z Konarów i Femka (żona Laczka) z Bystrzanowic (córki Dobiesława

$118 \mathrm{http}: / /$ www.slownik.ihpan.edu.pl/search.php?id=6193 [dostęp: 13.10.2018]. Podobnie UM, nr 163 (s. 71-72), gdzie jeszcze dokładniej szukano okręgu Mikołaja.

119 Z. Kaczmarczyk: Kasztelanowie konarscy. Studium o historii urzędów koronnych i nadwornych. „Czasopismo Prawno-Historyczne” 1949, T. 2, s. 18-20.

${ }^{120} \mathrm{KZK} 2$, nr 196 (s. 44).

${ }^{121} \mathrm{KZK} 2$, nr 1547 (s. 120).

${ }^{122} \mathrm{KZK} 2$, nr 1542 (s. 120).

${ }^{123} \mathrm{http}: / /$ www.slownik.ihpan.edu.pl/search.php?id=7828 [dostęp: 2.08 .2017$]$.

${ }^{124} \mathrm{http}: / / w w w . s l o w n i k . i h p a n . e d u . p l / s e a r c h . p h p ? i d=6193$ [dostęp: 13.10.2018].

${ }^{125} \mathrm{KZK} 2, \mathrm{nr} 3843$ (s. 257).

126 SPPP, T. 8, cz. 2, uwaga CCXXIX (nr 39 i 40, s. 402). Dnia 2 października t.r. sprawę z braćmi miała ich siostra Femka, uwaga nr CCXXX (nr 83, s. 408).

${ }^{127}$ SPPP, T. 8, cz. 2, uwaga CCXXX (nr 40, s. 407).

${ }^{128}$ SPPP, T. 8, cz. 2, nr 6383 (s. 455). 
z Ławszowa, obecnie Łapszów, h. Strzemię) miały na wiecu termin z (własnymi braćmi) Stanisławem i Jaszkiem z Ławszowa ${ }^{129}$. Dnia 4 marca 1398 r. Jakusz z Tczycy zobowiązał się ustąpić Zawiszy i jego matce (Dorocie) z rodzinnej części w Przestańsku, którą trzymał w zastawie na 30 grzywien ${ }^{130}$. Tego samego dnia Helena, żona Jakusza z Wilczkowic, godziła się z kmieciem (colonus) pani z Konarów ${ }^{131}$. W dniu 8 lipca 1398 r. Jakusz z Tczycy zobowiązał się zastawić do najbliższego czwartku za 30 grzywien groszy i 8 grzywien kwartników Dorocie z Konarów cztery łany w Tczycy płacące po jednej grzywnie czynszu, pod rygorem wzrostu długu do 50 grzywien ${ }^{132}$. Dnia 30 września 1398 r. z tymi braćmi miała apelację tylko sama Dorota, wdowa po Mikołaju z Konarów ${ }^{133}$. W dniu 3 lutego 1399 r. Dorota, wdowa po Mikołaju z Grodziny, przez okazanie dokumentu wydanego przez Kazimierza III Wielkiego pozyskała prawnie na Jaszku i Stanisławie z Lawszowa 1/4 dziedzin w Leśniowie i Zielenicach, pod warunkiem że wykupiłaby za własne pieniądze z zastawu część w Zielenicach. Bracia z siostrą Dorotą dokonali podziału Leśniowa dwa tygodnie po Popielcu ${ }^{134}$. W dniu 6 lutego 1399 r. Dorota z Konarów miała dalej sprawę ze Stanisławem i Jaszkiem z Ławszowa o 1/4 dóbr w Leśniowie (odesłano ją na wiec) ${ }^{135}$. Dnia 11 maja 1399 r. siostry Femka, żona Laczka z Bystrzanowic i Dorota (w dokumencie błędne imię Małgorzata - T.K.), wdowa z Konarów zwalniają ze sprawy swych braci Jaszka i Stanisława z Ławszowa o spadek obejmujący mienie po Piotrze Zieji ${ }^{136}$. Tego też dnia obie siostry z oboma braćmi zawarły ugodę we wszystkich spornych sprawach ${ }^{137}$. W dniu 10 maja 1400 r. Dorota, wdowa po Mikołaju z Grodziny, oraz (jej bracia) Jaszek i Stanisław z Ławszowa uzyskali termin na najbliższy wiec w sprawie dóbr po Piotrze Zieji. Cokolwiek postanowiliby w tej sprawie kasztelan krakowski Jan i wojewoda łęczycki Jan (Tarnowski), obie strony miały tego wieczyście przestrzegać138. W dniu 30 września $1400 \mathrm{r}$. Dorota wdowa po kasztelanie konarskim (castellani Conarsky) Mikołaju z Grodziny rezygnuje na rzecz synów: Zawiszy, Jaszka i Piotra z dóbr dziedzicznych oraz z posagu i wiana ${ }^{139}$.

129 SPPP, T. 8, cz. 2, uwaga CCXLIII (nr 1, s. 457). Sama Femka sądziła się z braćmi o 120 grzywien i o bezprawną kondemnatę, zob. nr 2-3, s. 457.

${ }^{130}$ SPPP, T. 8, cz. 2, nr 6654 (s. 485).

131 SPPP, T. 8, cz. 2, uwaga CCXLIX (nr 19, s. 486).

132 SPPP, T. 8, cz. 2, nr 7201 (s. 543).

133 SPPP, T. 8, cz. 2, uwaga CCLXV (nr 43, s. 581). Numery 44 i 45 sprawy Femki.

${ }^{134}$ SPPP, T. 8, cz. 2, nr 8189 (s. 646).

135 SPPP, T. 8, cz. 2, uwaga CCLXXX (nr 5, s. 658), zob. też nr 6 (sprawa między Staszkiem i Jaszkiem z Ławszowa a Laczkiem z Gorzkowa i jego żoną Femką o 120 grzywien i 1/2 dziedziny w Leśniowie odesłana na wiec).

136 SPPP, T. 8, cz. 2, nr 8754 (s. 706).

137 SPPP, T. 8, cz. 2, nr 8762 (s. 707).

138 SPPP, T. 8, cz. 2, nr 10087 (s. 852).

139 SPPP, T. 8, cz. 2, nr 10583 (s. 914). 


\section{Peterlin=Piotr}

W 1388 r. Peterlin ze Szczytnik procesował się z braćmi: (Mikołajem) kasztelanem z Konarów i Marciszem ${ }^{140}$. Występującego w 1394 r. Piotra z Konarów, mającego braci, identyfikował J. Kurtyka z Peterlinem ze Szczytnik z 1388 r. ${ }^{141}$. W dniu 15 sierpnia 1395 r. Petrus de Konari został jednym ze świadków Piotra ze Zdzi[e]sławic przeciwko Mikołajowi z tej wsi ${ }^{142}$. W dniu 8 czerwca $1396 \mathrm{r}$. Pietrasz z Konarów (Potrassius de Konari) procesował się z kmieciem Mikołajem z tej miejscowości o 11 jaj i o jagnięę4. W 1394 r. Jakusz z Konarów pozyskał na Piotraszu z Konarów część dziedzictwa w tej miejscowości. Piotr sądził się z Jakuszem o dzierżenie dóbr wbrew prawu ${ }^{144}$. Dnia 12 października 1396 r. toczył się dalej długotrwały spór Pietrasza z Konarów Jakuszem ${ }^{145}$. Dnia 19 czerwca 1397 r. Potrassius de Szechy został pozwany przez opata z Mogiły ${ }^{146}$.

\section{Tomek}

Dnia 19 lipca 1400 r. był wspomniany Tomek z Konarów jako nieżyjący, gdy Niemsta ze Skroniowa dał Krystynie, wdowie po nim, całą część zwaną Jabłończyńska w Desznie i 60 grzywien w zamian za połowę Rgilewa (Gylow, woj. łęczyckie) i czwartą część dziedziny w Zbylczycach (Zbilucice, woj. sieradzkie) ${ }^{147}$. Nic zgoła nie wiemy o tej postaci, ale spory rodzinne (zob. dalej) sugerują, że był to brat poprzedniej trójki i ojciec Jakuba, Przecława i Sieciecha. Ich ojcem raczej nie był Marcisz, obecnie brak informacji o jego małżeństwie.

${ }^{140} \mathrm{http}: / /$ www.slownik.ihpan.edu.pl/search.php?id=7828 [dostęp: 2.08 .2017 ].

${ }^{141} \mathrm{http}: / / \mathrm{www}$. slownik.ihpan.edu.pl/search.php?id=7828 [dostęp: 2.08.2017]. Autor ten dopuszczał też identyfikację tej postaci z jego bratankiem - imiennikiem.

${ }^{142} \mathrm{KZK} 2$, nr 3081 (s. 211).

${ }^{143} \mathrm{KZK} 2$, nr 4356 (s. 290).

${ }^{144} \mathrm{http}: / /$ www.slownik.ihpan.edu.pl/search.php?id=7828 [dostęp: 2.08.2017]. Dalszy termin zapewne w I 1396 r., bo sąd wyznaczył kolejny termin po święcie Oczyszczenia NMP [2 II], KZK2, nr 5229 (s. 345).

${ }^{145}$ KZK2, nr 4444 (s. 295). Kolejne terminy: 26 października 1396 r. (nr 4470, s. 296), 9 listopada 1396 r. (nr 4520, s. 299), 23 listopada 1396 r. (nr 4546, s. 301), 15 marca 1397 r. sąd wyznaczył kolejny termin na po święcie św. Stanisława w maju, nr 5383 (s. 353), 17 maja 1397 r. sąd wyznaczył termin po święcie Zesłania Ducha Świętego [wtedy 14 maja], nr 5473 (s. 360), 6 lipca 1397 r., nr 5573 (s. 366), 19 lipca 1397 r. sąd wyznaczył termin po św. Bartłomieju [24 sierpnia], nr 5609 (s. 368) i ostatecznie 6 września 1397 r. wyznaczył kolejny termin po św. Michale Archaniele [29 września], nr 5655 (s. 371).

146 SPPP, T. 8, cz. 2, uwaga CCXXII (nr 15, s. 388).

147 SPPP, T. 8, cz. 2, nr 10368 (s. 890). 


\section{Michat}

To samo można powiedzieć o Michale z Konarów. Dnia 3 lutego 1396 r. Jasiek z Mokrzesza w sprawie z Michałem z Konarów miał przyprowadzić proboszcza z Potoka Mikołaja. Miał złożyć zeznanie w poniedziałek po święcie Oczyszczenia NMP (2 lutego) na wiecu ${ }^{148}$.

\section{5-17. Zawisza, Jan i Piotr oraz 18. Jan}

Synowie Mikołaja i Doroty (zob. też wyżej): w 1401 r. Zawisza z Grodziny, poręczając za braci Jaszka i Piotrasza oraz matkę (Dorotę), przyrzekł wujowi Jaszkowi z Ławszowa, że nie będą go niepokoić o podział dziedziny w Zielenicach. W 1402 r. Zawisza z Grodziny zastawił za 30 grzywien groszy praskich Paszkowi z Bedlna dwóch kmieci w Młogolicach, płacących 3 grzywny czynszu. Występował do 1403 r. jako Zawisza z Konarów, Grodziny i Młogolic (dziś Cło w pow. Wiślickim) ${ }^{149}$. Natomiast jego brat Jaszek z Grodziny dał kasztelanowi krakowskiemu Janowi (z Tęczyna) wieś Zielenice w zamian za 300 grzywien groszy praskich i wieś Strzałków w ziemi sieradzkiej. Występował do 1402 r. $^{150}$. W 1404 r. Jaszek z Grodziny oddalił roszczenia wuja Jaszka z Ławszowa i innych $\mathrm{z}$ tytułu prawa bliższości do wsi Zielenice, okazując dokument sprzedaży tej wsi kasztelanowi krakowskiemu Janowi (z Tęczyna) i wykorzystując prawo przedawnienia. Zawisza z Grodziny był poświadczonym w latach 1398-1403 i 1414 - 1418, choć wtedy może chodzić o Zawiszę z Bełku. W latach 1403 1409 występował Jaszek lub Jan z Grodziny, będący synem Zawiszy ${ }^{151}$. Piotr pojawił się 30 września 1394 r. i 5 lutego 1398 r. (zob. wyżej). Był niepełnoletni jeszcze w 1397 r., notowano go do 1401 r. ${ }^{152}$.

\section{Jakub (Jakusz)}

W latach 1394-1397 był notowany Jakub lub Jakusz z Konarów. W 1394 r. Jakusz z Konarów pozyskał na (stryju) Piotraszu z Konarów część dziedzictwa $\mathrm{w}$ tej miejscowości. Piotr sądził się z Jakuszem o dzierżenie dóbr wbrew pra$w^{153}$. W 1394 r. Michał z Proszowic pozwał Mikołaja i (jego bratanka) Jakuba

\footnotetext{
${ }^{148} \mathrm{KZK} 2$, nr 3707 (s. 249).

$149 \mathrm{http}: / /$ www.slownik.ihpan.edu.pl/search.php?id=7828 [dostęp: 2.08 .2017 ].

${ }_{150} \mathrm{http}: / / \mathrm{www}$. slownik.ihpan.edu.pl/search.php?id=7828 [dostęp: 2.08 .2017 ]

$151 \mathrm{http}: / /$ www.slownik.ihpan.edu.pl/search.php?id=6193 [dostęp: 13.10.2018].

$152 \mathrm{http}: / /$ www.slownik.ihpan.edu.pl/search.php?id=7828 [dostęp: 2.08 .2017 ]

$153 \mathrm{http}: / /$ www.slownik.ihpan.edu.pl/search.php?id=7828 [dostęp: 2.08.2017].
} 
z Konarów o zabór pszenicy ${ }^{154}$. W dniu 23 marca 1396 r. (bracia) Jakusz, Przecław i Sieciech, dziedzice w Konarach, postanowili na zawsze zbyć część swego dziedzictwa (między sobą) za 30 grzywien groszy, w ten sposób, że każdy był zobowiązany do zapłaty 10 grzywien denarów i 13 grzywien denarów na dzień św. Mikołaja pod trzema grzywnami podatku na kolejny dzień św. Mikołaja, jeżeli spłacili trzy grzywny teraz z 10 pozostałych, zapłacić mieli dwie grzywny podatku, za co ręczyć mieli Jasiek z Łaganowa i Dziwisz z Przecławic ${ }^{155}$. Ten ostatni 16 stycznia 1397 r. powołał na świadka Jakusza z Konarów w sprawie przeciwko Piotraszowi ze Sieborowic ${ }^{156}$.

\section{Przeclaw}

W 1394 r. Marek i Halszka z Bojańczyc pozwali Przecława z Konarów ${ }^{157}$. Ostatni raz był odnotowany 23 marca 1396 r. (zob. wyżej).

\section{Sieciech}

Sieciech był odnotowany 23 marca 1396 r. (zob. wyżej).

\section{2-26. Paszek, Marcin i Piotr oraz Klemens i Krzychna}

Byli potomkami którejś z poprzednich osób. W latach 1416-1417 występował Paszek z Grodziny, brat Marcina i Piotra. W 1416 r. Paszek i Piotr z Grodziny zobowiązali się zapłacić 50 grzywien półgroszków z tytułu posagu swej siostrze Krzychnie, jeśli wyjdzie za mąż, i odkładać dla niej cztery grzywny czynszu rocznie na ręce brata Klemensa z Kliszowa (pow. Chęciński). W 1417 r. Paszek z Grodziny nie stawił się na termin z siostrą Krzychną z Kars (pow. Wiślicki) o 50 grzywien jej posagu i tyleż kary. W latach 1410 - 1447 wymieniany był Piotr Lisek z Grodziny i Lubachów, brat Paszka. W 1427 r. Piotr z Grodziny sprzedał za 35 grzywien część w Dziewięczycach. Marcisz z Kars zeznał, że Piotr zwany Lisek z Grodziny zapłacił mu 14 grzywien z tytułu zastawu w Grodzinie. Paszek pozostawił córkę Elżbietę, ostatnią dziedziczkę Konarów.

\footnotetext{
${ }^{154} \mathrm{http} / / /$ www.slownik.ihpan.edu.pl/search.php?id=7828 [dostęp: 2.08.2017].

155 KZK2, nr 4230 (s. 281).

${ }^{156} \mathrm{KZK} 2$, nr 4933 (s. 323).

$157 \mathrm{http}: / /$ www.slownik.ihpan.edu.pl/search.php?id=7828 [dostęp: 2.08 .2017 ].
} 


\section{Elżbieta}

W 1456 r. Jan (Piotraszowic) Kaliński Wiechetek z Kaliny Wielkiej wyznaczył żonie Elżbiecie, córce zmarłego Paszka z Konarów, po 125 grzywien posagu i wiana na połowie dóbr w Kalinie Wielkiej i Polanowicach. W 1459 r. Jan Kaliński Piotraszowic zeznał, że Paweł Paszek z Konarów z żoną Elżbietą zapłacili mu 100 kop groszy posagu ich córki Elżbiety ${ }^{158}$.

Przedstawione tu źródła historycznoprawne mają niewątpliwie wycinkowy charakter, ale pozwalają na zorientowanie się, jak wyglądał obrót prawny w okresie średniowiecza.

\section{Bibliografia}

\section{Źródla drukowane}

Archiwum ksiażą Lubartowiczów Sanguszków w Sławucie. Wyd. Z.L. Radzimiński, B. Gorczak. T. 2: (1284-1506). Lwów 1888.

Dokumenty sadu ziemskiego krakowskiego 1302-1453. Oprac. Z. Perzanowski. Wrocław-Warszawa-Kraków-Gdańsk 1971.

Federowicz K.: Dostojnicy i urzędnicy świeccy województwa krakowskiego w latach 1374-1506. W: Archiwum Komisji Historycznej. T. 8. Kraków 1898.

Kodeks Dyplomatyczny Katedry Krakowskiej św. Wacława. Wyd. F. Piekosiński. T. 2. Kraków 1883.

Kodeks dyplomatyczny Matopolski. T. 3: 1333-1386. Wyd. F. Piekosiński. Kraków 1887.

Kodeks dyplomatyczny Matopolski. [T. 1]: 1178-1386. Wyd. F. Piekosiński. Kraków 1876.

Kodeks dyplomatyczny miasta Krakowa 1253-1506. Cz. 1. Wyd. F. Piekosiński. Kraków 1879.

Kodeks dyplomatyczny Polski. T. 1. Red. L. Rzyszczewski. Warszawa 1847.

Kodeks dyplomatyczny Polski. T. 3. Wyd. L. Rzyszczewski, A. Muczkowski. Warszawa 1858.

Kodeks dyplomatyczny Wielkopolski. Lata 1350-1399. Wyd. J.I. Kraszewski (dr W. Łebiński). T. 3. Poznań 1879.

Księga ziemska krakowska 2. 1394-1397. Wyd. W. Bukowski, M. Zdanek. Warszawa 2012.

${ }^{158} \mathrm{http}: / /$ www.slownik.ihpan.edu.pl/search.php?id=7111 [dostęp: 13.10.2018]. 
Sikora F.: Morsko Dolne i Górne. W: Słownik historyczno-geograficzny województwa krakowskiego w średniowieczu. Red. W. Bukowski. T. 4, z. 4. Kraków 2014.

Starodawne prawa polskiego pomniki. T. 8: Antiquissimi libri iudiciales terrae cracouiensis. Pars I: Ab an. 1374-1390. Editionem curauit B. Ulanowski. Cracoviae A. MDCCCLXXXIV.

Starodawne prawa polskiego pomniki z ksiag rękopiśmiennych dotąd nieużytych gtówniej zaś z ksiag dawnych sądowych ziemskich i grodzkich ziemi krakowskiej. Wyciągnął i wydał A.Z. Helcel. T. 2. Kraków 1870.

Starodawne prawa polskiego pomniki. T. 8: Antiquissimi libri iudiciales terrae cracouiensis. Pars II: Ab an. 1394-1400. Editionem curauit B. Ulanowski. Cracoviae MDCCCLXXXVI.

Urzędnicy dawnej Rzeczypospolitej XII-XVIII wieku. Spisy. Red. A. Gąsiorowski. T. IV/1: Urzędnicy małopolscy XII-XV wieku. Spisy. Oprac. J. Kurtyka, T. Nowakowski, F. Sikora, A. Sochacka, P.K. Wojciechowski, B. Wyrozumska. Wrocław 1990.

Zbiór dokumentów małopolskich. Cz. 1: Dokumenty z lat 1257-1420. Wyd. S. Kuraś. Wrocław-Warszawa-Kraków 1962.

Zbiór dokumentów małopolskich. Cz. 4: Dokumenty z lat 1211-1400. Wyd. S. Kuraś, I. Sułkowska-Kuraś. Wrocław-Warszawa-Kraków 1969.

\section{Opracowania}

Bardach J.: Historia państwa i prawa Polski. T. 1: Do połowy XV wieku. Warszawa 1973.

Kaczmarczyk Z.: Kasztelanowie konarscy. Studium o historii urzędów koronnych i nadwornych. „Czasopismo Prawno-Historyczne” 1949, T. 2.

Kruszewski T.: Panowie z Grodziny herbu Szreniawa. Analiza historycznoprawna [w druku].

\section{Źródla elektroniczne}

http://www.slownik.ihpan.edu.pl/search.php?id=6193 [dostęp: 13.10.2018]. http://www.slownik.ihpan.edu.pl/search.php?id=7111 [dostęp: 13.10.2018]. http://www.slownik.ihpan.edu.pl/search.php?id=7817 [dostęp: 13.10.2018]. http://www.slownik.ihpan.edu.pl/search.php?id=7830 [dostęp: 13.10.2018]. http://www.slownik.ihpan.edu.pl/search.php?id=7828 [dostęp: 13.10.2018]. http://www.slownik.ihpan.edu.pl/search.php?id=25381 [dostęp: 13.10.2018]. 
Tomasz Kruszewski

\section{Erben von Konary vom Wappen Ostoja und Szreniawa Eine historisch-rechtliche Analyse}

Schlüsselwörter: Mittelalter, Kleinpolen, Rechtsverkehr, Kastellanei, Oberhofstallmeister, Konary $=$ Pferdesport

Zusammenfassung: Der Autor zeigt das mittelalterliche Dorf Konary, dessen Name darauf hinweist, dass es sich um ein Dienstdorf des Krakauer Kastellans von Konary handelte. Im 14. Jahrhundert war es jedoch selbst eine ,übliche“ Kastellanei, die von Mikołaj von Grodzina verwaltet wurde. Die Güter im Dorf wurden von zwei Familien geteilt: Ritter von Grodzina, Wappen Szreniawa, und andere von Koszyce (Pilsner Kreis), Wappen Ostoja. Im Artikel wird der Rechtsverkehr mit deren Beteiligung beschrieben.

Tomasz Kruszewski

\section{Heirs of Konary of Ostoja and Szreniawa coats of arms Historical and legal analysis}

Keywords: Middle Ages, Lesser Poland, legal turnover, castellany, konarski=equerry

Summary: The author shows the medieval village of Konary, whose name indicates that it was a servile village of the Konary castellan of Cracow. However, in the 14th century, it was an "ordinary" castellany run by Mikołaj from Grodzina. The estate in the village was divided by two families: knights from Grodzina village of the Szreniawa coat of arms and those from Koszyce (district of Pilsen) of the Ostoja coat of arms. The article is a description of legal transactions with their participation. 
